\title{
Shifts in Circulating Concentrations of Glucose in Domesticated Mammals: Is There a Consistent Adaptation to Domestication?
}

\author{
Colin G. Scanes \\ Department of Biological Science, University of Wisconsin Milwaukee, Milwaukee, USA \\ Email: scanes@uwm.edu
}

Received 1 July 2014; revised 5 August 2014; accepted 15 August 2014

Copyright (C) 2014 by author and Scientific Research Publishing Inc.

This work is licensed under the Creative Commons Attribution International License (CC BY).

http://creativecommons.org/licenses/by/4.0/

c) (i) Open Access

\section{Abstract}

There have been marked changes in amylase gene number during human evolution resulting in shifts in carbohydrate metabolism. This has been related to utilization of starch. Similarly, there are changes in enzymes related to carbohydrate metabolism in dogs. Again, this has been linked to improving starch utilization following domestication. It was questioned as circulating concentrations of glucose is a good indicator of putative differences in carbohydrate metabolism across domesticated animals. Domesticated bovids had lower $(p<0.001)$ circulating concentrations of glucose than wild species in their respective sub-families. Circulating concentrations of glucose were consistently lower $(p<0.001)$ in domesticated animals compared to either closely related wild species or the mean for wild species in their sub-families (or families where there is insufficient data available). It is suggested that shift to lower circulating concentrations of glucose in domesticated animals is related to greater starch intake following domestication in a manner akin to the shifts in carbohydrate metabolism and amylase gene number in human evolution.

\section{Keywords}

Circulating Glucose, Livestock, Domestication

\section{Introduction}

The ability both to digest dietary poly/disaccharides and to absorb monosaccharides is critically important. Moreover, it is crucial to control carbohydrate metabolism and maintain circulating concentrations of glucose in animals as much as in people. During human evolution, there has been the acquisition of multiple copies of amylase gene (AMY1). This presumably allows greater utilization of starch (earlier work reviewed [1] [2]). 
Concentrations of amylase in the saliva are related to amylase gene copy number; there being markedly higher amylase concentrations with increasing numbers of amylase 1 genes [2] [3]. Elevated amylase is associated with improvements in both the digestion of starchy foods [3] [4] and in glucose tolerance [5]. Following consumption of starch, there were smaller increases in circulating concentrations of glucose in subjects with high compared to those with low salivary amylase concentrations [5]. Moreover, plasma concentrations of insulin rose earlier [5]. In contrast, $A M Y 1$ gene number does not show the increases in frugivorous chimpanzees (Pan troglodytes) and bonobos (Pan paniscus) [2]. The present communication examines whether analogous shifts in carbohydrate metabolism occurred during domestication of mammals with the increases in consumption of starch in the diet.

It has recently been suggested that the ability to thrive on a diet rich in starch was a key feature in the early domestication of dogs. There are signals of selection being reported in ten genes related to starch digestion and fat metabolism in dogs [6]. The impact of these genomic shifts on glucose metabolism in dogs has not been reported. It is questioned whether there may be marked differences in circulating concentrations of glucose in dogs compared to the ancestral grey wolf. Moreover, there is a single report that circulating concentrations of glucose are lower in domesticated pigs than in wild pigs [7]. The aim of the present study was to determine whether there is a systematic shift in the basal circulating concentrations of glucose in domesticated species.

\section{Materials and Methods}

\subsection{Database}

There is a large but diffuse literature containing data on serum biochemistry and hematological parameters of wild animals, most commonly determined on blood samples obtained at capture. A database of basal plasma/ serum glucose concentrations in vertebrate species was assembled based on the literature to allow analysis of putative physiological shifts with evolutionary/taxonomic status, ecological parameters and other environmental factors. Circulating concentrations of glucose would be expected to exhibit marked differences e.g. between fed and fasted in mono-gastric omnivorous animals. However, domestic animals and the descendants of their ancestral wild species are predominantly either ancestrally carnivores or either rumen or hind gut fermenters relying on gluconeogenesis. Circulating concentrations of glucose is widely reported as a serum/plasma biochemical parameter in wild mammals following capture.

On causal inspection of the database, there appeared to be a relationship between domestication and serum/ plasma concentration of glucose with lower levels in domesticated species. The data base was then queried systematically to determine whether circulating concentrations of glucose are different in domesticated species compared to either descendant of the ancestral species or to the taxonomic sub-family or family which the domesticated species belongs.

\subsection{Statistical Analysis}

Comparisons between circulating concentrations of glucose in domesticated species and descendants of the same (or very closely related) species or the mean for the sub-family [and where there is available data on insufficient numbers of species $(n<3)$ — the family] were analyzed by both Student's paired $t$ test and by split plot analysis of variance (ANOVA) followed by Tukey's range test.

\section{Results}

Table 1 and Table 2 summarize circulating concentrations of glucose in domesticated animals and, respectively, either animals of closely related wild species or the means for wild animals in the sub-families (or where there are insufficient data points in families). The circulating concentrations of glucose were uniformly lower in domesticated animals than descendant animals of the ancestral species of the domestic animals or those in closely related wild species (Table 1). Moreover, within the exception of the cat, circulating concentrations of glucose were lower in domesticated animals than in wild species of their respective sub-families/families (Table 2).

Table 3 compares the circulating concentrations of glucose in domesticated and the respective wild species (Table 1 and Table 2). Circulating concentrations of glucose are 33.7\% lower $(\mathrm{p}<0.001)$ in domesticated animals compared to matched ancestral or closely related wild mammalian species and $40.1 \%$ lower $(\mathrm{p}<0.001)$ in domesticated animals and wild species than in their respective sub-families/families (Table 3).

There was a marked difference $(\mathrm{p}<0.001)$ in the circulating concentrations of glucose between domesticated 
Table 1. Comparison of circulating concentrations of glucose in domestic and closely related/ancestral wild species.

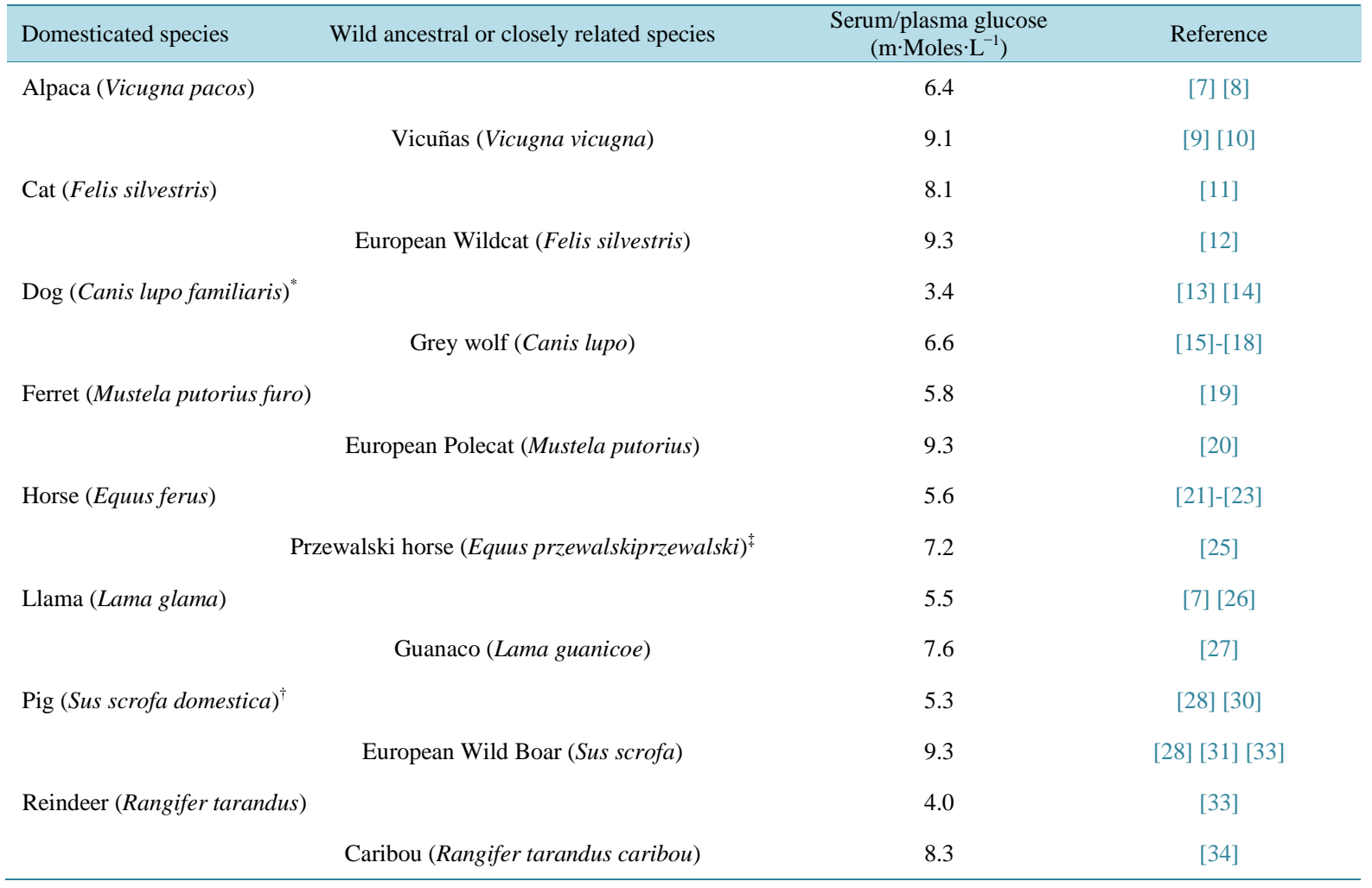

*Compared to $3.1 \mathrm{~m} \cdot$ Moles $\cdot \mathrm{L}^{-1}$ in stray dogs [35]; ${ }^{\dagger}$ The only surviving true wild horse species [24]; ${ }^{\dagger}$ Compared to $7.8 \mathrm{~m} \cdot$ Moles $\cdot \mathrm{L}^{-1}$ in Texas feral pigs [36].

animals and wild species in the taxonomic sub-families Bovinae and Caprinae in the Family Bovidae (Table 3). Circulating concentrations of glucose were $57.1 \%$ lower in domesticated bovids (Table 3).

\section{Discussion}

Circulating concentrations of glucose were consistently lower in domesticated animals than in either matched ancestral species/closely related wild mammalian species (Table 1 and Table 3) or other members of the same taxonomic sub-family/family (Table 2 and Table 3). The difference in circulating concentrations of glucose in domesticated animals is a general phenomenon. These were observed irrespective of the following:

- Nutrition-i.e. whether the domesticated species was a ruminant, hind gut fermenter (horse, ass and rabbit) or predominantly carnivore (dog, ferret).

- Classification/evolutionary relationships—being observed in species from the Orders-Actiodactyla (bovids, camelids, deer and pigs), Carnivora (dogs, ferrets), Lagomorpha (rabbits) and Perissodactyla (horses and donkeys).

Genomic studies in dogs and horses support a shift in carbohydrate metabolism in domesticated species with increasing consumption of starch. The ability to thrive on a diet rich in starch was a key feature in the early domestication of dogs. Signals of selection have been reported in ten genes related to starch digestion and metabolism in dogs [6]. Moreover in horses, there is evidence again for selection for genes related to carbohydrate metabolism [50].

The present communication would support it being the selection associated with domestication itself rather than subsequently being response for the difference in circulating concentrations of glucose. There was not a relationship $\left(r^{2}<0.2 ; p>0.45\right)$ between the duration of time since domestication and the differences in circulating concentrations of glucose between domesticated animals and either closely related wild species or the mean for the sub-family/family (data not shown).

While the domestic cat is considered within the domestic animals, it can be argued that cats should be consi- 
Table 2. Comparison of circulating concentrations of glucose with wild members of the same sub-family or family.

\begin{tabular}{|c|c|c|c|}
\hline Domesticated Species & Wild Species in Same Taxonomic Group & $\begin{array}{l}\text { Serum/Plasma Glucose } \\
\left(\mathrm{m} \cdot \text { Moles } \cdot \mathrm{L}^{-1}\right)\end{array}$ & Reference \\
\hline \multicolumn{2}{|c|}{ Cattle (Bos primigenius formerly Bos taurus) ${ }^{a}$} & 5.2 & [37] [38] \\
\hline \multicolumn{2}{|c|}{ Gayal-Domesticated Gaur (Bos gaurus) } & 2.7 & [39] \\
\hline \multicolumn{2}{|c|}{ Water Buffalo (Bubalus bubalis) } & 3.2 & [40] \\
\hline & Non-Domesticated-Subfamily Bovinae $e^{\ddagger}$ & $8.0 \pm(8) 0.6$ & \\
\hline \multicolumn{2}{|l|}{ Sheep (Ovis aries) } & 4.1 & [41] [42] \\
\hline \multicolumn{2}{|c|}{ Goat (Capra aegagrus hircus) } & 4.2 & [43] [44] \\
\hline & Non-Domesticated-Subfamily Caprinae ${ }^{\ddagger}$ & $9.4 \pm(6) 0.7$ & \\
\hline \multicolumn{2}{|l|}{ Alpaca (Vicugna pacos) } & 6.4 & [7] [8] \\
\hline \multicolumn{2}{|c|}{ Camel (Camelus dromedaries) } & 4.1 & [26] [45] \\
\hline \multirow[t]{2}{*}{ Llama (Lama glama) } & & 5.5 & [7] [26] \\
\hline & Non-Domesticated-Family Camelidae ${ }^{\ddagger}$ & $8.3 \pm(2) 0.8$ & \\
\hline \multicolumn{2}{|c|}{ Pig (Sus scrofa domestica) } & 5.3 & {$[28]-[30]$} \\
\hline & Non-Domesticated-Family Suidae $e^{\ddagger}$ & $6.1 \pm(4) 1.14$ & \\
\hline \multicolumn{2}{|c|}{ Reindeer (Rangifer tarandus) } & 4.0 & [33] \\
\hline & Non-Domesticated-Family Cervidae $e^{\ddagger}$ & \multicolumn{2}{|c|}{$7.9 \pm(14) 0.5$} \\
\hline \multicolumn{2}{|c|}{ Dog (Canis lupo familiaris) } & 3.4 & [13] [14] \\
\hline & Non-Domesticated-Subfamily Caninae ${ }^{\ddagger}$ & $7.1 \pm(11) 0.8$ & \\
\hline \multirow[t]{2}{*}{ Cat (Felis silvestris) } & & 8.1 & [11] \\
\hline & Non-Domesticated Subfamily Felinae ${ }^{\ddagger}$ & $7.6 \pm(11) 0.8$ & \\
\hline \multicolumn{2}{|c|}{ Ferret (Mustela putorius furo) } & 5.8 & [19] \\
\hline & Non-Domesticated Subfamily Mustelinae ${ }^{\ddagger}$ & 9.5 & \\
\hline \multicolumn{2}{|c|}{ Donkey or Ass (Equus africanus asinus) } & 4.1 & [23] [46] [48] \\
\hline \multirow[t]{2}{*}{ Horse (Equus ferus) } & & 5.6 & [21] [23] \\
\hline & Non-Domesticated-Family Equidae $e^{\ddagger}$ & $7.6 \pm(5) 0.6$ & \\
\hline \multicolumn{2}{|c|}{ Rabbit (Oryctolagus cuniculus) } & 6.8 & [13] [49] \\
\hline & Non-Domesticated-Family Leporidae ${ }^{\ddagger}$ & $10.2 \pm(4) 1.6$ & \\
\hline
\end{tabular}

dered as commensal rather than domesticated [51]. Cats are obligate carnivores that were “domesticated” about 5300 BP [51] [52]. Selection is thought to have been focused traits related to hunting ability [51] [52]. It is not surprising that cats are on outlier with little, if any, difference in circulating concentrations of glucose with either a closely related species (Table 1 ) or wild species within the (Table 2).

It might be argued that the greater circulating concentration of glucose in wild species is an artifact of their capture, environment or nutritional state. This does not appear to be the case. Similar concentrations of glucose are reported in captive wolves and those in the wild [53]. Moreover, there was no difference in circulating concentrations of glucose between fed and fasted states in wolves [15].

It might be questioned as to whether the lower concentration of glucose in domestic animals reflects an effect of human activity. One way to address this is comparison of glucose in domesticated animals that have reverted 
Table 3. Comparison of circulating concentrations of glucose mean + $(n=)$ S.E.M. in domesticated and wild species.

Serum/Plasma Glucose $\left(\mathrm{m} \cdot\right.$ Moles $\left.\cdot \mathrm{L}^{-1}\right)$

I. Comparison between domesticated animals and wild species in the Bovidae subfamilies Bovinae and Caprinae

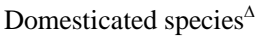

$3.9 \pm(5) 0.53^{\mathrm{a}}$

Wild species

$8.6 \pm(14) 0.50^{b}$

II. Comparison between domesticated animals and matched ancestral or closely related wild mammalian species ${ }^{\Delta}$

Domesticated species

$5.5 \pm(8) 0.51^{\mathrm{a}}$

Ancestral or closely related wild species

$8.3 \pm(8) 0.38^{b}$

III. Comparison between domesticated animals and mean for wild species within same family or subfamily ${ }^{\dagger}$

Domesticated species $^{\Delta}$

$4.9 \pm(16) 0.36^{\mathrm{a}}$

Matched family or sub-family wild species

$8.2 \pm(16) 0.25^{\mathrm{b}}$

${ }^{\Delta}$ Data shown in Table 1; ${ }^{\dagger}$ Where information is available on sufficient species $(>3)$; data shown in Table 2; ${ }^{\text {a,b }}$ Different superscript letters indicate difference $\mathrm{p}<0.001$.

to the wild. Circulating concentrations of glucose in feral adult horses, stray dogs and feral goats are the same as in domesticated animals [35] [54] [56] but higher in young burros [57] and wild horses samples at some locations [54]. It is unclear the extent to which feral pigs in the USA represent the descendants of introduced Eurasian wild pigs/wild boar (Sus scrofa) [58] and/or escaped domesticated pigs. The assumption is that feral pigs are predominantly Eurasian wild pigs. The range where feral pigs are found is increasing in part by further introductions. Circulating concentrations of glucose in feral pigs in the Texas, USA (7.8 mM) [36] are between those of wild pigs $(9.3 \mathrm{mM})$ and domestic pigs $(3.7 \mathrm{mM}$ ) (Table 1$)$. This supports feral pigs, at least in Texas, being the result of hybridization between wild pigs and escaped domestic pigs. Based on circulating concentrations of glucose, it is estimated that about three quarters of the background of feral pigs is from wild pigs.

The present study provides evidence that domesticated animals have reduced circulating concentrations of glucose. What is not known include the following: Do the differences in circulating concentrations of glucose reflect amylase gene number as in humans [1]-[5] and dogs [6]? Is there are systematic shifts in the "set point" of the homeostatic mechanism in domestic animals including insulin secretion? Are there assumptions about ideal diets that do not adequately address differences in domestication?

\section{Acknowledgements}

The helpful discussions with colleagues, and particularly with Dr. Selvakumar Ramakrishnan, are gratefully acknowledged.

\section{References}

[1] Meisler, M.H. and Ting, C.N. (1993) There Markable Evolutionary History of the Human Amylase Genes. Critical Reviews in Oral Biology and Medicine, 4, 503-509.

[2] Perry, G.H., Dominy, N.J., Claw, K.G., Lee, A.S., Fiegler, H., Redon, R., Werner, J., Villanea, F.A., Mountain, J.L., Misra, R., Carter, N.P., Lee, C. and Stone, A.C. (2007) Diet and the Evolution of Human Amylase Gene Copy Number Variation. Nature Genetics, 39, 1256-1260. http://dx.doi.org/10.1038/ng2123

[3] Santos, J.L., Saus, E., Smalley, S.V., Cataldo, L.R., Alberti, G., Parada, J., Gratacòs, M. and Estivill, X. (2012) Copy Number Polymorphism of the Salivary Amylase Gene: Implications in Human Nutrition Research. Journal of Nutrigenetics and Nutrigenomics, 5, 117-131. http://dx.doi.org/10.1159/000339951

[4] Mandel, A.L., Peyrot des Gachons, C., Plank, K.L., Alarcon, S. and Breslin, P.A. (2010) Individual Differences in AMY1 Gene Copy Number, Salivary $\alpha$-Amylase Levels, and the Perception of Oral Starch. PLoS One, 5, Article ID: e13352. http://dx.doi.org/10.1371/journal.pone.0013352

[5] Mandel, A.L. and Breslin, P.A. (2012) High Endogenous Salivary Amylase Activity Is Associated with Improved Glycemic Homeostasis Following Starch Ingestion in Adults. Journal of Nutrition, 142, 853-858.

http://dx.doi.org/10.3945/jn.111.156984 
[6] Axelsson, E., Ratnakumar, A., Arendt, M.L., Maqbool, K., Webster, M.T., Perloski, M., Liberg, O., Arnemo, J.M., Hedhammar, A. and Lindblad-Toh, K. (2013) The Genomic Signature of Dog Domestication Reveals Adaptation to a Starch-Rich Diet. Nature, 495, 360-364. http://dx.doi.org/10.1038/nature11837

[7] Araya, A.V., Atwater, I., Navia, M.A. and Jeffs, S. (2000) Evaluation of Insulin Resistance in Two Kinds of South American Camelids: Llamas and Alpaca. Comparative Medicine, 50, 490-494.

[8] Dawson, D.R., DeFrancisco, R.J., Mix, S.D. and Stokol, T. (2011) Reference Intervals for Biochemical Analytes in Serum and Heparinized Plasma and Serum Protein Fractions in Adult Alpacas (Vicugna pacos). Veterinary Clinical Pathology, 40, 538-548.

[9] Bonacic, C. and MacDonald, D.W. (2003) The Physiological Impact of Wool-Harvesting Procedures in Vicunas (Vicugna vicugna). Animal Welfare, 12, 387-402.

[10] Siguas, O. and Olazábal, J. (2008) Perfil sanguíneo de vicuñas del CICDC Lachocc Huancavelica. Archivos de Zootecnia, 57, 87-90.

[11] Chugani, H.T., Hovda, D.A., Villablanca, J.R., Phelps, M.E. and Xu, W.F. (1991) Metabolic Maturation of the Brain: A Study of Local Cerebral Glucose Utilization in the Developing Cat. Journal of Cerebral Blood Flow and Metabolism, 11, 35-47. http://dx.doi.org/10.1038/jcbfm.1991.4

[12] Marco, I., Martinez, F., Pastor, J. and Lavin, S. (2000) Hematologic and Serum Chemistry Values of the Captive European Wildcat. Journal of Wildlife Disease, 36, 445-449. http://dx.doi.org/10.7589/0090-3558-36.3.445

[13] Wolford, S.T., Schroer, R.A., Gohs, F.X., Gallo, P.P., Brodeck, M., Falk, H.B. and Ruhren, R. (1986) Reference Range Data Base for Serum Chemistry and Hematology Values in Laboratory Animals. Journal of Toxicology and Environmental Health, 18, 161-188. http://dx.doi.org/10.1080/15287398609530859

[14] Lumsden, J.H., Mullen, K. and McSherry, B.J. (1979) Canine Hematology and Biochemical Reference Values. Canadian Journal of Comparative Medicine, 43, 125-131.

[15] Delgiudice, G.D., Seal, U.S. and Mech L.D. (1987) Effects of Feeding and Fasting on Wolf Blood and Urine Characteristics. Journal of Wildlife Management, 51, 1-10. http://dx.doi.org/10.2307/3801752

[16] Constable, P., Hinchcliff, K., Demma, N., Callahan, M., Dale, B., Fox, K., Adams, L., Wack, R. and Kramer, L. (1998) Serum Biochemistry of Captive and Free-Ranging Gray Wolves (Canis lupus). Journal of Zoo and Wildlife Medicine, 29, 435-440.

[17] Butler, M.J., Ballard, W.B. and Whitlaw, H.A. (2006) Physical Characteristics, Hematology and Serum Biochemistry of Free-Ranging Gray Wolves, Canis lupus, in Southeast Alaska. Canadian Field-Naturalist, 120, 205-212.

[18] Thoresen, S.I., Arnemo, J.M. and Liberg, O. (2009) Hematology and Serum Clinical Chemistry Reference Intervals for Free-Ranging Scandinavian Gray Wolves (Canis lupus). Veterinary Clinical Pathology, 38, 224-229. http://dx.doi.org/10.1111/j.1939-165X.2008.00105.x

[19] Lee, E.J., Moore, W.E., Fryer, H.C. and Minocha, H.C. (1982) Haematological and Serum Chemistry Profiles of Ferrets (Mustela putorius furo). Lab Animals, 16, 133-137. http://dx.doi.org/10.1258/002367782781110241

[20] Mustonen, A.M., Puukka, M., Rouvinen-Watt, K., Aho, J., Asikainen, J. and Nieminen, P. (2009) Response to Fasting in an Unnaturally Obese Carnivore, the Captive European Polecat Mustela putorius. Experimental Biology and Medicine (Maywood), 234, 1287-1295. http://dx.doi.org/10.3181/0904-RM-140

[21] Christensen, R.A., Malinowski, K., Massenzio, A.M., Hafs, H.D. and Scanes, C.G. (1997) Acute Effects of Short-Term Feed Deprivation and Refeeding on Circulating Concentrations of Metabolites, Insulin-Like Growth Factor I, Insulin-Like Growth Factor Binding Proteins, Somatotropin, and Thyroid Hormones in Adult Geldings. Journal of Animal Science, 75, 1351-1581.

[22] Nadal, M.R., Thompson, D.L. and Kincaid, L.A. (1997) Effect of Feeding and Feed Deprivation on Plasma Concentrations of Prolactin, Insulin, Growth Hormone, and Metabolites in Horses. Journal of Animal Science, 75, 736-744.

[23] Simenew, K., Gezahegne, M., Getachew, M., Wondyefraw, M., Alemayehu, L. and Eyob, I. (2011) Reference Values of Clinically Important Physiological, Hematological and Serum Biochemical Parameters of Apparently Healthy Working Equids of Ethiopia. Global Veterinaria, 7, 1-6.

[24] Orlando, L.,Ginolhac, A., Zhang, G., Froese, D., Albrechtsen, A., Stiller, M., Schubert, M., Cappellini, E., Petersen, B., Moltke, I., Johnson, P.L., Fumagalli, M., Vilstrup, J.T., Raghavan, M., Korneliussen, T., Malaspinas, A.S., Vogt, J., Szklarczyk, D., Kelstrup, C.D., Vinther, J., Dolocan, A., Stenderup, J., Velazquez, A.M., Cahill, J., Rasmussen, M., Wang, X., Min, J., Zazula, G.D., Seguin-Orlando, A., Mortensen, C., Magnussen, K., Thompson, J.F., Weinstock, J., Gregersen, K., Røed, K.H., Eisenmann, V., Rubin, C.J., Miller, D.C., Antczak, D.F., Bertelsen, M.F., Brunak, S., Al-Rasheid, K.A., Ryder, O., Andersson, L., Mundy, J., Krogh, A., Gilbert, M.T., Kjær, K., Sicheritz-Ponten, T., Jensen, L.J., Olsen, J.V., Hofreiter, M., Nielsen, R., Shapiro, B., Wang J. and Willerslev, E. (2013) Recalibrating Equus Evolution Using the Genome Sequence of an Early Middle Pleistocene Horse. Nature, 499, 74-78. http://dx.doi.org/10.1038/nature12323 
[25] Kutter, C. and Wiesner, H. (1987) Changes of Blood Values in Przewalski Horses (Equus przew alski przew alski) and Zebras (Equus zebra hartmannae) during Chemical Immobilization. Journal of Zoo Animal Medicine, 18, 144-147. http://dx.doi.org/10.2307/20094827

[26] Fowler, M.E. (2003) Camelidae. In: Fowler, M.E. and Miller, R.E., Eds., Zoo and Wild Animal Medicine, 5th Edition, Saunders, St. Louis, 612-625.

[27] Karesh, W.B., Uhart, M.M., Dierenfeld, E.S., Braselton, W.E., Torres, A., House, C., Puche, H. and Cook, R.A. (1998) Health Evaluation of Free-Ranging Guanaco (Lama guanicoe). Journal of Zoo and Wildlife Medicine, 29, $134-141$.

[28] Harapin, I., Bedrica, L., Hahn, V., Šoštarić, B. and Gračner, D. (2003) Haematological and Biochemical Values in Blood of Wild Boar (Sus scrofa ferus). Veterinarski Archiv, 73, 333-343.

[29] Iozzo, P., Gastaldelli, A., Järvisalo, M.J., Kiss, J., Borra, R., Buzzigoli, E., Viljanen, A., Naum, G., Viljanen, T., Oikonen, V., Knuuti, J., Savunen, T., Salvadori, P.A., Ferrannini, E. and Nuutila, P. (2006) 18F-FDG Assessment of Glucose Disposal and Production Rates during Fasting and Insulin Stimulation: A Validation Study. Journal of Nuclear Medicine, 47, 1016-1022.

[30] Chmielowiec-Korzeniowska, A., Leszek, T. and Babicz, M. (2012) Assessment of Selected Parameters of Biochemistry, Hematology, Immunology and Production of Pigs Fattened in Different Seasons. Archiv fuer Tierzucht, 55, 469479.

[31] Williamson, M.J. (1972) Some Hematological and Serum Biochemical Values of European Wild Hogs (Sus scrofa). Master's Thesis, University of Tennessee, Knoxvile.

[32] Vidal, D., Naranjo, V., Mateo, R., Gortazar, C. and de la Fuente, J. (2006) Analysis of Serum Biochemical Parameters in Relation to Mycobacterium bovis Infection of European Wild Boars (Sus scrofa) in Spain. European Journal of Wildlife Research, 52, 301-304. http://dx.doi.org/10.1007/s10344-006-0062-2

[33] Nieminen, M. (1980) Nutritional and Seasonal Effects on the Haematology and Blood Chemistry in Reindeer (Rangifer tarandus tarandus L.). Comparative Biochemistry and Physiology, 66, 399-413. http://dx.doi.org/10.1016/0300-9629(80)90186-3

[34] Johnson, D., Harms, N.J., Larter, N.C., Elkin, B.T., Tabel, H. and Wei, G. (2010) Serum Biochemistry, Serology, and Parasitology of Borial Caribou (Rangifer tarandus caribou) in the North West Territories, Canada. Journal of Wildlife Disease, 46, 1096-1107. http://dx.doi.org/10.7589/0090-3558-46.4.1096

[35] Khan, S.A., Epstein, J.H., Olival, K.J., Hassan, M.M., Hossain, M.B., Rahman, K.B.M.A., Elahi, M.F., Mamun, M.A., Haider, N., Yasin G. and Desmond, J. (2011) Hematology and Serum Chemistry Reference Values of Stray Dogs in Bangladesh. Open Veterinary Journal, 1, 13-20.

[36] Shender, L.A., Botzler, R.G. and George, T.L. (2002) Analysis of Serum and Whole Blood Values in Relation to Helminth and Ectoparasite Infections of Feral Pigs in Texas. Journal of Wildlife Disease, 38, 385-394. http://dx.doi.org/10.7589/0090-3558-38.2.385

[37] McAtee, J.W. and Trenkle, A. (1971) Effect of Feeding, Fasting and Infusion of Energy Substrates on Plasma Growth Hormone Levels in Cattle. Journal of Animal Science, 33, 612-616.

[38] McAtee, J.W. and Trenkle, A. (1971) Effects of Feeding, Fasting, Glucose or Arginine on Plasma Prolactin Levels in the Bovine. Endocrinology, 89, 730-734. http://dx.doi.org/10.1210/endo-89-3-730

[39] Akhatar, M.Z., Khan, A., Khan, M.Z. and Javaid, A. (2008) Patho-Biochemical Changes in Buffaloes (Bubalus bubalis) Suffering from Parturient Haemoglobinuria. Pakistan Veterinary Journal, 28, 139-143.

[40] Nath, N.C., Hazarika, B.C., Nath, K.C., Thapa, D. and Upadhyaya, T.N. (1983) Hematologic and Blood Chemistry Profiles of the Captive Gayal (Bos gaurus frontalis). Journal of Zoo Animal Medicine, 14, 102-106. http://dx.doi.org/10.2307/20094652

[41] McDonald, S.E., Paul, S.R. and Bunch, T.D. (1981) Physiologic and Hematologic Values in Nelson Desert Bighorn Sheep. Journal of Wildlife Disease, 17, 131-134. http://dx.doi.org/10.7589/0090-3558-17.1.131

[42] Pell, J.M. and Bergman, E.N. (1983) Cerebral Metabolism of Amino Acids and Glucose in Fed and Fasted Sheep. American Journal of Physiology, 244, E282-E289.

[43] Pelligrino, D.A., Miletich, D.J. and Albrecht, R.F. (1987) Time Course of Radiolabeled 2-Deoxy-D-Glucose 6Phosphate Turnover in Cerebral Cortex of Goats. American Journal of Physiology, 252, R276-R283.

[44] Schwalm, J.W. and Schultz, L.H. (1976) Blood and Liver Metabolites in Fed and Fasted Diabetic Goats. Journal of Dairy Science, 59, 262-269. http://dx.doi.org/10.3168/jds.S0022-0302(76)84193-8

[45] Asadi, F., Shahriari, A., Asadian, P., Pourkabir, M., Sabzikar, A. and Ojaghee, R. (2009) Serum Lipid, Glucose, Free Fatty Acids and Liver Triglyceride in Sub-Adult and Adult Camels (Camelus dromedarius). Revue de Médecine Vétérinaire, 160, 552-556.

[46] Zinkl, J.G., Mae, D., Guzman Merida, P., Farver, T.B. and Humble, J.A. (1990) Reference Ranges and the Influence of 
Age and Sex on Hematologic and Serum Biochemical Values in Donkeys (Equus asinus). American Journal of Veterinary Research, 51, 408-413.

[47] Caldin, M., Furlanello, T., Solano-Gallego, L., De Lorenzi, D., Carli, E., Tasca, S. and Lubas, G. (2005) Reference Ranges for Haematology, Biochemical Profile and Electrophoresis in a Single Herd of Ragusana Donkeys from Sicily (Italy). Comparative Clinical Pathology, 14, 5-12. http://dx.doi.org/10.1007/s00580-005-0544-8

[48] Tesfaye, T., Mamo, G., Endebu, B. and Abayneh, T. (2012) Comparative Serum Biochemical Profiles of Three Types of Donkeys in Ethiopia. Comparative Clinical Pathology, 24, 1-8.

[49] Prasad, K. (2008) Serum Biochemical Changes in Rabbits on a Regular Diet with and without Flax Lignan Complex Following a High-Cholesterol Diet. International Journal of Angiology, 17, 27-32. http://dx.doi.org/10.1055/s-0031-1278276

[50] Park W., Kim J., Kim, H.J., Choi, J., Park, J.W., Cho, H.W., Kim, B.W., Park, M.H., Shin, T.S., Cho, S.K., Park, J.K., Kim, H., Hwang, J.Y., Lee, C.K., Lee, H.K., Cho, S. and Cho, B.W. (2014) Investigation of de Novo Unique Differentially Expressed Genes Related to Evolution in Exercise Response during Domestication in Thoroughbred Race Horses. PLoS ONE, 9, e91418. http://dx.doi.org/10.1371/journal.pone.0091418

[51] Bar-Oz, G., Weissbrod, L. and Tsahar, E. (2014) Cats in Recent Chinese Study on Cat Domestication Are Commensal, Not Domesticated. Proceedings of the National Academy of Sciences of the United States of America, 111, E876. http://dx.doi.org/10.1073/pnas.1324177111

[52] Hu, Y., Hu, S., Wang, W., Wu, X., Marshall, F.B., Chen, X., Hou, L. and Wang, C. (2014) Earliest Evidence for Commensal Processes of Cat Domestication. Proceedings of the National Academy of Sciences of the United States of America, 111, 116-120. http://dx.doi.org/10.1073/pnas.1311439110

[53] Seal, U.S. and Mech, L.D. (1983) Blood Indicators of Seasonal Metabolic Patterns in Captive Adult Gray Wolves. Journal of Wildlife Management, 47, 704-715. http://dx.doi.org/10.2307/3808606

[54] Borchard, R.E., Vaughan, H.W., Gallagher, L.V. and Schmidt, S.L. (1982) Biochemical Constituents in Domestic and Wild Horses I. Semen Proteins, Electrolytes and Metabolites. Journal of Equine Veterinary Science, 2, 119-126. http://dx.doi.org/10.1016/S0737-0806(82)80004-X

[55] Seal, U.S., Siniff, D.B., Tester, J.R. and Williams, T.D. (1985) Chemical Immobilization and Blood Analysis of Feral Horses (Equus caballus). Journal of Wildlife Disease, 21, 411-416. http://dx.doi.org/10.7589/0090-3558-21.4.411

[56] Freudenberger, D.O. and Nolan, J.V. (1993) Glucose Metabolism in a Kangaroo (Macropus robustus erubescens) and a Similar Size Eutherian Herbivore, the Feral Goat. Comparative Biochemistry and Physiology, 106, 295-298. http://dx.doi.org/10.1016/0300-9629(93)90515-6

[57] Davis, T.P., Yousef, M.K., El-Nouty, F.D. and Johnson, H.D. (1978) Hormonal, Hematologic and Other Biochemical Constituents in the Burro Equus asinus. Journal of Equine Medicine and Surgery, 2, 389-392.

[58] Mayer, J.J. and Lehr Brisbin Jr., I. (1991) Wild Pigs of the United States: Their History, Morphology and Current Status. University of Georgia Press, Athens. 
Scientific Research Publishing (SCIRP) is one of the largest Open Access journal publishers. It is currently publishing more than 200 open access, online, peer-reviewed journals covering a wide range of academic disciplines. SCIRP serves the worldwide academic communities and contributes to the progress and application of science with its publication.

Other selected journals from SCIRP are listed as below. Submit your manuscript to us via either submit@scirp.org or Online Submission Portal.
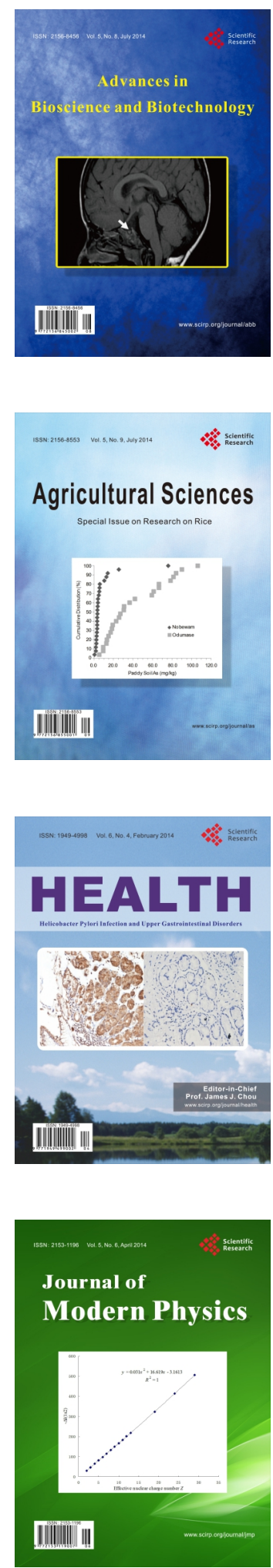
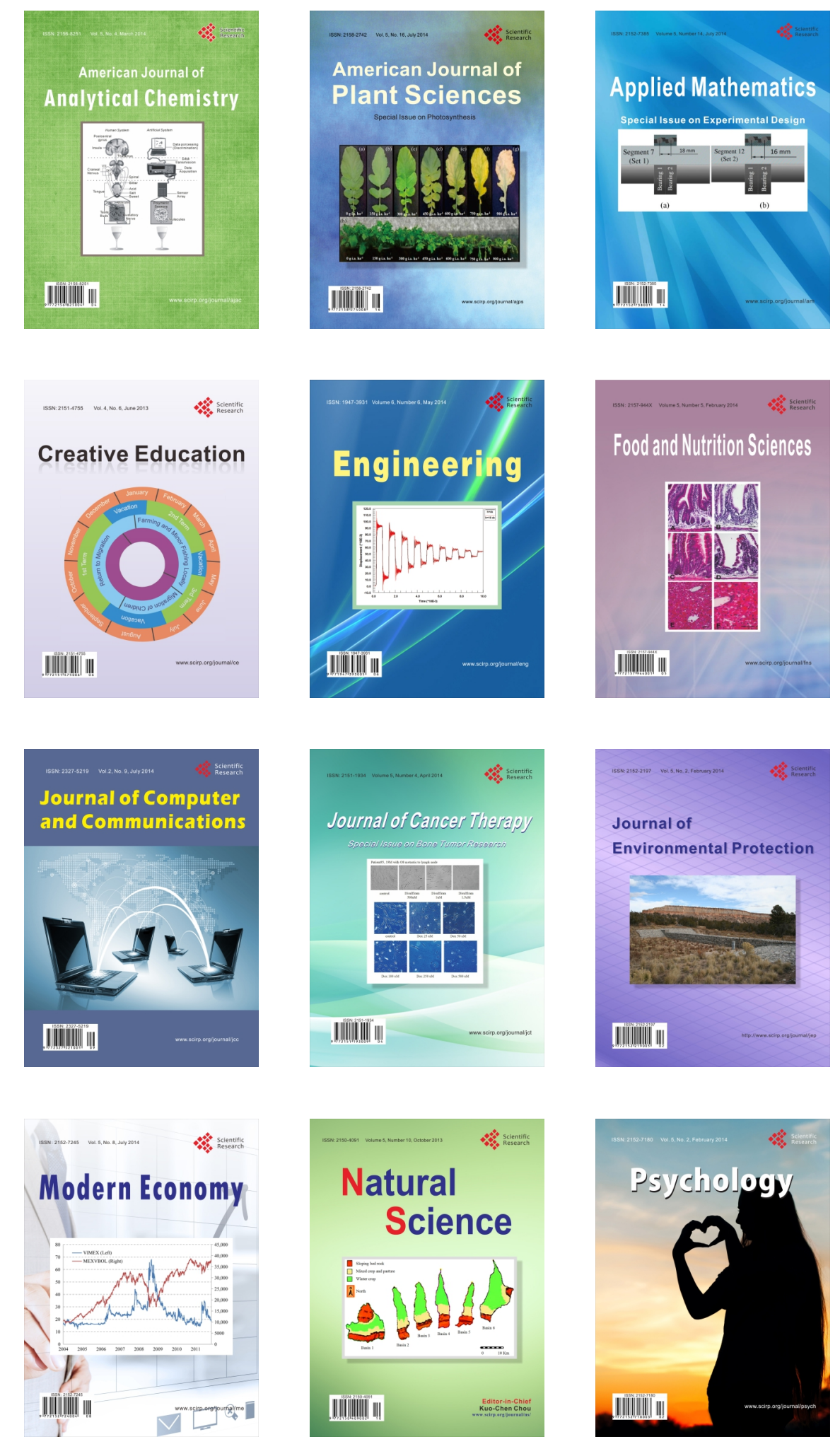